\title{
Penerapan Diabetes Self Management Education (DSME) dalam Meningkatkan Self Care Penderita Diabetes Melitus
}

\author{
Yureya Nita ${ }^{1}$, Angga Arfina $^{2}$, Yeni Devita ${ }^{3}$, Stephanie Dwiguna ${ }^{4}$ \\ rheamouse@gmail.com, angga_arfina@yahoo.com, yenidevita@payungnegeri.ac.id, \\ guna5291@gmail.com \\ 1,2,3,4 STIKes Payung Negeri Pekanbaru
}

\begin{abstract}
Article History:
Received: 16-06-2021

Revised: 22-07-2021

Accepted: 22-07-2021
\end{abstract}

Keywords: Diabetes mellitus, self-management, self-care

\begin{abstract}
Diabetes mellitus (DM) is a chronic disease that occurs due to the body's inability to carry out the metabolism of carbohydrates, fats and proteins due to an insulin defect. DM is progressive, this will cause the patient to experience hyperglycemia which can increase glucose levels in the blood. In 2015, there were about 415 million adults with diabetes. This service activity is expected to provide information about educational programs for DM sufferers and involve their families to prevent further complications, as well as increase independence in self-care and quality of life for DM sufferers. The method of implementing this service is by checking vital signs, measuring blood sugar, providing health education about DM and evaluating with an education method based on DSME (Diabetes Self Management Education). This activity was attended by 17 participants in the first and second activities and 15 people in the third activity. The results of this service were attended by most of the participants having blood sugar levels when they were above normal (> $140 \mathrm{mg} / \mathrm{dL}$ ), which was in accordance with the target of the participants and went quite well. Overall self-management education activities to improve self-care for DM patients can be said to be successful.
\end{abstract}

\section{Pendahuluan}

Diabetes melitus (DM) merupakan salah satu penyakit kronis yang terjadi akibat ketidakmampuan tubuh untuk melakukan proses metabolisme karbohidrat, lemak dan protein akibat adanya defek insulin. DM bersifat progresif, hal ini akan menyebabkan penderita mengalami hiperglikemia yang dapat meningkatkan kadar glukosa dalam darah (Atak et al., 2008). DM telah menjadi salah satu kasus endemi hampir di seluruh dunia. Saat ini, DM menjadi salah satu prioritas penyakit tidak menular yang berdampak menimbulkan berbagai komplikasi antara lain kebutaan, serangan jantung, penyakit stroke, gagal ginjal dan amputasi. (Federation \& Hulp, 2015). Menurut Centers for Disease Control and Prevention (CDC) tahun 2011, DM mempengaruhi 25, 8 juta orang atau sekitar 8,3\% populasi di Amerika (F, 1967).

Berdasarkan data IDF (Federation \& Hulp, 2015) hampir $80 \%$ DM terjadi di negara 
dengan berpenghasilan rendah dan menengah. Indonesia merupakan salah satu negara yang memiliki populasi DM tertinggi di dunia. Indonesia menempati urutan peringkat ke tujuh dengan jumlah estimasi penderita DM yaitu 10 juta orang. Prevalensinya cenderung meningkat dari 5,7\% (2007) menjadi 6,9\% (2013). Hal ini menggambarkan bahwa DM merupakan penyakit kronis yang membutuhkan penanganan yang kompleks.

Salah satu penatalaksanaan yang dapat dilakukan oleh tenaga kesehatan adalah memberikan pendidikan kesehatan yang berkesinambungan. Kegiatan ini dapat dilakukan secara individu maupun berkelompok dalam membantu klien mengelola kondisi kronis tersebut (Arfina, 2019). Salah satu program edukasi yang dapat dilakukan adalah berdasarkan program Diabetes Self Management Edukasi (DSME). Pada program ini penderita DM difasilitasi untuk mendapatkan informasi mengenai pengetahun, keterampilan serta meningkatkan kemampuan untuk melakukan self care (perawatan diri) yang optimal (Funnell et al., 2012). Beberapa perilaku self care yang sangat penting pada penderita DM antara lain mengatur diet yang sehat, melakukan aktivitas fisik, kontrol gula darah, mematuhi program pengobatan, koping yang efektif, perilaku pencegahan risiko serta kemampuan memecahkan masalah yang baik (Srivastava et al., 2015). DSME dirancang untuk membantu dalam memberikan pendidikan manajemen diri penderita DM dalam beberapa rangkaian kegiatan. Pemberian edukasi sangat efektif memperbaiki hasil klinis dan kualitas hidup penderita (Funnell et al., 2012).

Penderita DM yang mendapatkan edukasi yang benar dan berkesinambungan dapat mambatu mereka untuk mengelola perawatan diri akibat penyakitnya. Melalui pemberian program edukasi berbasis DSME diharapkan penderita DM mampu mencegah komplikasi yang dapat muncul. Selain itu berpartisipasi dalam program pendidikan manajemen diri dapat meningkatkan keterampilan penderita mengelola diabetes secara lebih efektif dengan memeriksa gula darah secara teratur, diet sehat, melakukan aktivitas fisik, minum obat sesuai resep dokter, serta menangani stres akibat diabetes (Report, 2020).

Berdasarkan uraian pada latar belakang tersebut maka perlu dilakukannya pemberian edukasi berbasis DSME kepada masyarakat yang menderita DM melalui kegiatan pengabdian masyarakat. Kegiatan ini dilakukan agar masyarakat yang menderita DM mendapatkan informasi yang benar dalam mengelola penyakitnya sehingga dapat mencegah terjadinya komplikasi serta meningkatkan kemandirian dalam perawatan diri.

\section{Metode}

Metode yang digunakan dalam pengabdian kepada masyarakat ini adalah dengan service learning, yaitu pembelajaran atau edukasi kepada layanan masyarakat. Tahap https://journal.universitasbumigora.ac.id/index.php/ADMA 
perencanaan yang dilakukan dengan persiapan proposal dan administrasi, media, leaflet, power point, serta peralatan pengukuran tanda-tanda vital, dan alat pengukur gula darah. Kegiatan pengabdian masyarakat ini dilaksanakan pada bulan maret 2019 s/d Juli 2019, di Kelurahan Agrowisata Kecamatan Rumbai, dengan sasaran masyarakat penderita DM di Kelurahan Agrowisata. Pengabdian masyarakat dilaksanakan dengan cara tatap muka serta latihan bagaimana cara meningkatkan self care pada penderita DM berjalan dengan baik dan lancar.

Kegiatan ini pertama-ttama dilakukan persiapan, yaitu persiapan bahan administrasi, surat menyurat, materi, leaflet, power point, serta persiapan media yang akan digunakan untuk kegiatan. Tahap selanjutnya pelaksanaan kegiatan yaitu pelaksanaan tekanan darah, serta pengukuran gula darah, dilanjutkan dengan dilakukannya penyuluhan kesehatan tentang DM. Pelaksanaan selanjutnya yaitu penerapan edukasi berbasis DSME, dan evaluasi penerapan berbasis DSME.

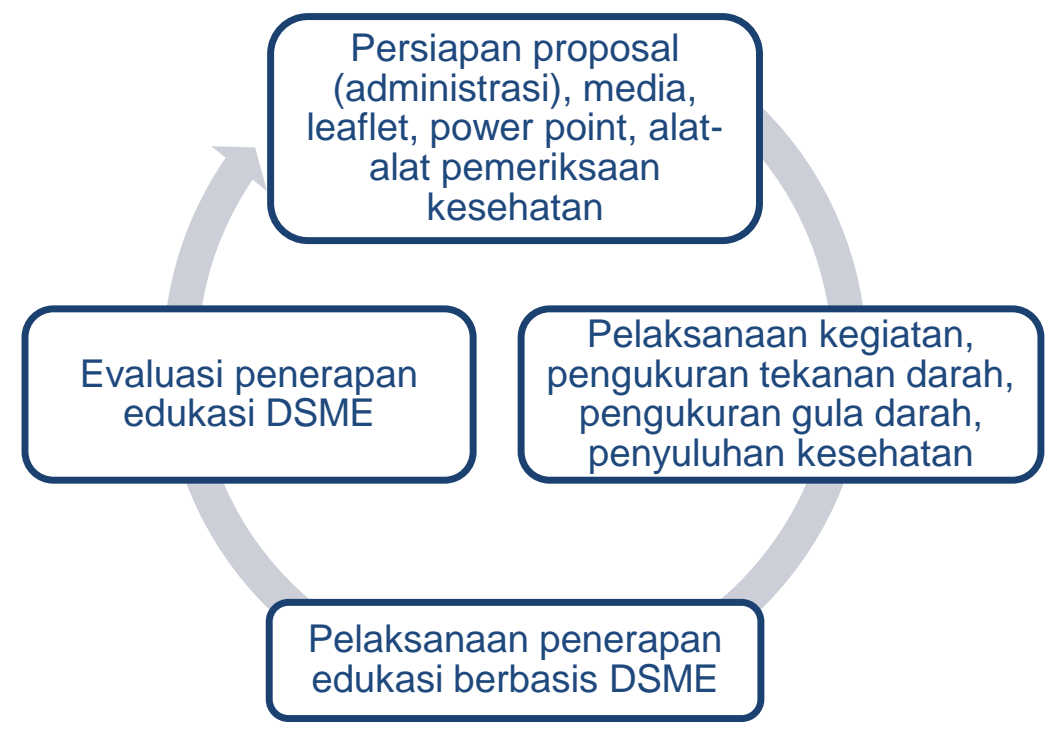

Gambar 1. Metode pelaksanaan pengabdian

\section{Pembahasan}

Kegiatan pengabdian masyarakat yang dilaksanakan dengan cara tatap muka serta latihan bagaimana cara meningkatkan self care pada penderita DM berjalan dengan baik dan lancar. Pertemuan tatap muka dengan metode ceramah atau penyuluhan dan demonstrasi dilanjutkan dengan pemeriksaan gula darah serta latihan bagaimana cara perawatan DM pada penderita ataupun anggota keluarga yang menderita DM.

Pelaksanaaan Kegiatan Pertama : dilaksanakan pada tanggal 11 April 2019 dari pukul 13.30 - 15.45 WIB di Kelurahan Agrowisata Kecamatan Rumbai Kota Pekanbaru. Peserta kegiatan ini adalah warga yang berjumlah 17 orang yang rata-rata berusia 30 tahun https://journal.universitasbumigora.ac.id/index.php/ADMA 
ADMA

Gurnal Pengabdian dan Pemberdayaan Masyarakat
2021, Vol.2, No.1, pp. 65-72

Doi: $10.30812 /$ adma.v2i1.1277

ke atas. Mata pencaharian dari warga yang datang pada umumnya adalah ibu rumah tangga dan petani. Pada kegiatan pertama ini dilakukan pemeriksaan kesehatan yaitu pengukur kadar gula darah dan tekanan darah serta penyuluhan tentang penyakit diabetes melitus (DM). Dari keterangan warga yang hadir sebagian besar sering merasa lemas dan mempunyai kadar glukosa darah yang cukup tinggi.

Pelaksanaaan kegiatan kedua: dilaksanakan pada tanggal 18 April 2019 dari pukul 10.00 - 12.00 WIB di Kelurahan Agrowisata Kecamatan Rumbai Kota Pekanbaru. Peserta kegiatan ini adalah warga yang berjumlah 17 orang yang rata-rata berusia 30 tahun ke atas. Kegiatan kedua ini dilaksanakan dengan metode ceramah atau penyluhan dan praktek tentang pengaturan diet pada penderita DM.

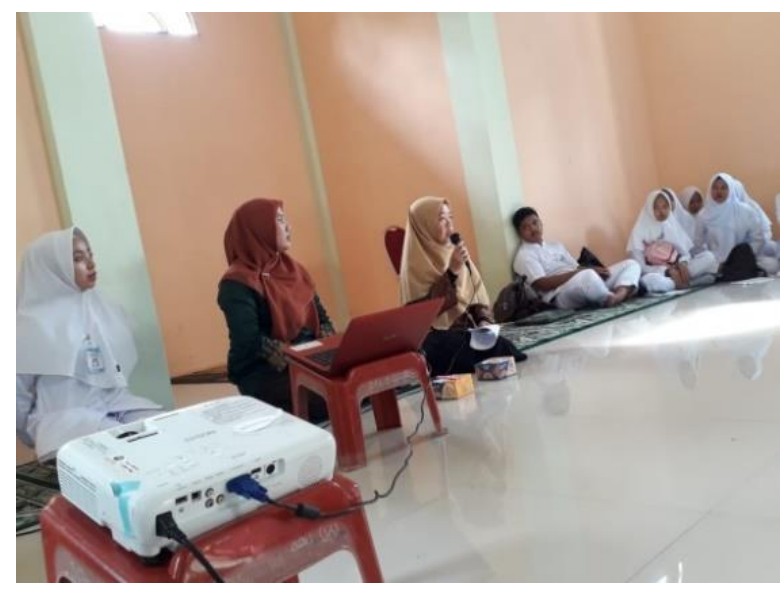

Gambar 2. Proses pelaksanaan kegiatan

Pelaksanaan Kegiatan Ketiga : dilaksanakan pada tanggal 03 Mei 2019 dari pukul 13.30 - 15.00 WIB di Kelurahan Agrowisata Kecamatan Rumbai Kota Pekanbaru. Peserta kegiatan ini adalah warga yang berjumlah 15 orang yang rata-rata berusia 30 tahun ke atas. Kegiatan ketiga ini adalah kegiatan terakhir dari kegiatan pengabdian masyarakat ini. Pada kegiatan terakhir ini metode pelaksanaannya adalah tatap muka untuk mengevaluasi kadar glukosa darah warga yang menderita DM dan perawatan DM yang telah diberikan. Dari 15 warga yang hadir, 7 orang diantaranya telah melakukan pengaturan diet atau makanan yang tekah didemonstrasikan serta telah menghindari makanan yang tidak dianjurkan untuk penderita DM. Hal ini terlihat dari hasil pengukuran glukosa warga yang menunjukkan adanya penurunan.

Pada kegiatan pengabdian masyarakat ini, disetiap masing-masing kegiatan juga dilakukan sesi tanya jawab dengan peserta yang hadir. Kegiatan pengabdian pada masyarakat berupa penerapan edukasi manajemen diri penderita DM dalam meningkatan perawatan diri di Kelurahan Agrowisata Kecamatan Rumbai Kota Pekanbaru yang telah dilaksanakan ini diharapkan dapat menambah pengetahuan, wawasan dapat melakukan 
perawatan diri dengan baik dan benar sehingga mampu mencegah terjadinya komplikasi serta meningkatkan status kesehatan penderita DM.

Tercapainya target peserta kegiatan ini yang sebelumnya direncanakan adalah paling tidak 10 peserta yang memiliki riwayat penyakit DM. Dalam pelaksanaannya, kegiatan ini diikuti oleh 17 peserta pada kegiatan pertama dan kedua serta 15 orang pada kegiatan ketiga. Peserta yang hadir pada kegiatan tersebut sebagian besar memiliki kadar gula darah sewaktu diatas normal (> $140 \mathrm{mg} / \mathrm{dL}$ ). Dengan demikian dapat dikatakan bahwa target peserta tercapai $100 \%$. Angka tersebut menunjukkan bahwa kegiatan pengabdian masyarakat dilihat dari jumlah peserta yang hadir dapat dikatakan sukses.

Ketercapaian tujuan kegiatan secara umum sudah baik, dimana semua pokok bahasan tentang DM sudah disampaikan secara keseluruhan dengan baik dan benar. Materi yang disampaikan adalah, Pengertian Diabetes melitus, Kadar gula darah normal, Penyebab diabetes melitus, Faktor risiko yang dapat menyebabkan DM, Klaisifikasi DM, Tanda dan gejala DM, Komplikasi DM, Perawatan DM, Syarat diet atau makanan pada penderita DM, Jadwal pemberian diate pada penderita DM, Komposisis diet yang digunakan, Jenis makanan yang dianjurkan pada penderita DM, Jenis makanan yang tidak dianjurkan untuk penderita DM, Contoh menu untuk penderita DM.

Ketercapaian target demonstrasi pengaturan diet DM pada kegiatan ini cukup baik, karena demonstrasi pengaturan diet telah dilakukan dengan baik dan benar sesuai dengan daftar menu DM yang telah disiapkan, hal tersebut dibuktikan dengan aktifnya para peserta demonstrasi mengikuti kegiatan demonatrasi dan ikut mencoba kegiatan pengaturan diet saat dicontohkan kepada peserta, dan hal ini juga dapat terlihat juga dari antusias warga dalam bertanya dan menjawab pertanyaan seputar DM Keterbatasan waktu dalam demonstrasi pengaturan diet DM tidak bisa dilakukan untuk semua jenis atau menu yang telah disusun..

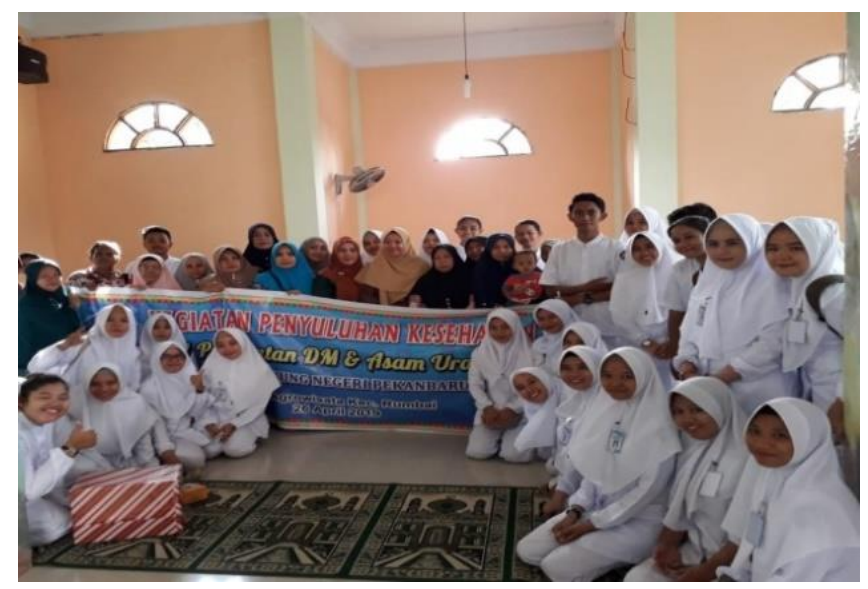

Gambar 3. Dokumentasi kegiatan pengabdian kepada masyarakat 


\section{Kesimpulan}

Kegiatan penerapan edukasi manajemen diri untuk meningkatkan self care pada penderita DM telah dilaksanakan dengan baik dan berjalan lancar sesuai dengan rencana kegiatan yang telah disusun. Walaupun masih ada beberapa warga 7 dari 15 orang warga yang belum menerapkan dalam pengaturan diet untuk penderita DM namun dari hasil pemeriksaan gula darah masih dalam batas normal. Kegiatan ini juga mendapat sambutan yang baik dari warga Kelurahan Agrowisata Kecamatan Rumbai Kota Pekanbaru. Hal ini dapat dilihat dari keaktifan warga dalam mengikuti setiap kegiatan dengan tidak meninggalkan tempat sebelum waktu kegiatan berakhir serta antusias saat bertanya dan menjawab pertanyaan.

\section{Ucapan terimakasih}

Ucapan terimakasih kami ucapkan kepada semua pejabat dan rekan-rekan yang telah membantu pelaksanaan kegiatan pengabdian kepada masyarakat ini. Secara khusus kami ucapkan terima kasih kepada :

1. Ketua STIKes Payung Negeri Pekanbaru yang telah memberikan kesempatan dan izin dalam melaksanakan pengabdian

2. Ketua program studi S1 Keperawatan STIKes Payung Negeri

3. Lurah dan warga Kelurahan Agrowisata Kecamatan Rumbai, Pekanbaru

4. Mahasiswa Prodi S1 Keperawatan STIKes Payung Negeri Pekanbaru yang telah membantu dan berpartisipasi untuk suksesnya kegiatan pengabdian

5. Berbagai pihak yang membantu dalam terlaksananya kegiatan ini

\section{Daftar pustaka}

Arfina, A. (2019). Pengaruh Edukasi Pengaturan Diet Terhadap Perilaku Pengelolaan Diet Pada Penderita Diabetes Melitus Di Kelurahan Agrowisata Kecamatan Rumbai Kota Pekanbaru. Indonesian Trust Health Journal, 2(2), 246-251. https://doi.org/10.37104/ithj.v2i2.41

Atak, N., Gurkan, T., \& Kose, K. (2008). The effect of education on knowledge, self management behaviours and self efficacy of patients with type 2 diabetes. Australian Journal of Advanced Nursing, 26(2), 66-74.

F, K. Ge. (1967). 済無No Title No Title No Title. In Angewandte Chemie International Edition, 6(11), 951-952.

Federation, I. D., \& Hulp, C. De. (2015). Update of mortality attributable to diabetes for the IDF Diabetes Atlas: Estimates for the year 2013. Diabetes Research and Clinical Practice, 109(3), 461-465. https://doi.org/10.1016/j.diabres.2015.05.037

Funnell, M. M., Brown, T. L., Childs, B. P., Haas, L. B., Hosey, G. M., Jensen, B., Maryniuk, M., Peyrot, M., Piette, J. D., Reader, D., Siminerio, L. M., Weinger, K., \& Weiss, M. A. (2012). National standards for diabetes self-management education. Diabetes Care, 35(SUPPL. 1). 


\section{ADMA}

Gurnal Pengabdian dan Pemberdayaan Masyarakat
2021, Vol.2, No.1, pp. 65-72

Doi: 10.30812/adma.v2i1.1277

https://doi.org/10.2337/dc12-s101

Report, N. D. S. (2020). National Diabetes Statistics Report, 2020. National Diabetes Statistics Report, 2.

Srivastava, P. K., Srivastava, S., Singh, A. K., \& Dwivedi, K. N. (2015). Role of Ayurveda in Management of Diabetes Mellitus. International Research Journal of Pharmacy, 6(1), 8-9. https://doi.org/10.7897/2230-8407.0613 


\section{ADMA}

Gurnal Pengabdian dan Pemberdayaan Masyarakat
2021, Vol.2, No.1, pp. 65-72

Doi: $10.30812 /$ adma.v2i1.1277 